\title{
Patrimonio histórico-artístico de Peñíscola
}

\author{
Isidro Marimón Cruces
}

\section{Motivación}

Desarrollar y hacer una exposición sobre el patrimonio histórico de Peñíscola ofrece una oportunidad de adentrarnos en la cultura, el arte y el pasado de su población. Los diferentes monumentos a los que me referiré no son más que la expresión colectiva de los diferentes momentos históricos que vivieron sus habitantes a lo largo de su dilatada historia.

Hay que hacer referencia obligada a que el casco antiguo de Peñíscola fue declarado conjunto histórico artístico en el año 1972, el castillo templario está declarado monumento histórico artístico nacional desde el año 1922 y la ciudad de Peñíscola tiene desde el siglo xviII, por mandato de Felipe V en 1709 , los títulos de muy noble, muy leal y fidelísima ciudad. Estas tres circunstancias históricas nos dan una idea de la trayectoria de sus gentes y del reflejo que las mismas han plasmado a lo largo de los años, expresado en sus monumentos.

La población de Peñíscola tiene en su conjunto una serie de monumentos que conforman su patrimo-

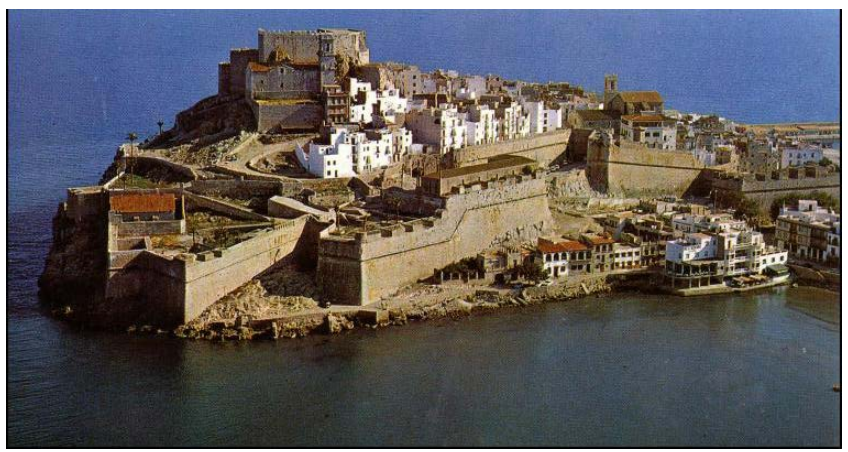

Figura 1. Castillo-palacio de Peñíscola nio histórico. Revisaremos sus características, los periodos en que fueron construidos y los estilos arquitectónicos; enumeraremos los siguientes dada su importancia: castillo templario, murallas del antiguo contorno urbano, portal de Felipe iI o portal Fosc, portal de San Pedro o del Papa Luna, iglesia parroquial de Santa María, casa de las conchas y la ermita de la Virgen de la Ermitana.

El castillo de Peñíscola (figura 1), también conocido como castillo del Papa Luna, se encuentra emplazado en la parte más elevada del peñón que domina la población, con una altura media de sesenta y cuatro metros sobre el mar; su perímetro es de doscientos treinta metros y tiene una altura media de muralla externa de veinte metros. Los cristianos de la época acostumbraban a repartirse las tierras antes de conquistarlas. En el año de 1146, Ramón Berenguer IV hizo donación del castillo a su principal consejero de gobierno, Guillermo Ramón de Moncada. En el año 1235, ya en manos de la Corona de Aragón, se decide que el castillo pertenece a la Corona. En 1286, el rey Alfonso hace donación del castillo y villa a don Artal de Alagón, el cual lo mantendrá en su poder hasta el año 1293, año en el que pasa a manos del rey de Aragón Jaime II el Justo, pasando de nuevo a la Corona de Aragón. Un año más tarde, en 1294, lo permutó a la Orden del Temple por la ciudad y alfoz de Tortosa.

Jaime I intentó tomarla en el año de 1225 pero no fue hasta el año de 1233, después de la caída de Burriana, cuando Peñíscola se entregó sin lucha a las tropas del rey aragonés, siéndole concedida la carta del fuero de Valencia en 1250. El castillo que hoy 
conocemos se empezó a construir en el año 1294 sobre una antigua fortaleza musulmana y fue terminado doce años más tarde, en el año 1307, por los caballeros de la Orden del Temple. Se puede considerar, por tanto, un castillo templario. Fue construido durante el mandato del maestre de la orden, Berenguer de Cardona.

La Orden del Temple fue una de las más famosas órdenes militares cristianas, siendo aprobada dicha orden en el año 1129 durante el Concilio de Troyes. Dicha orden creció de forma rápida en tamaño y poder y sus miembros no combatientes en las cruzadas gestionaban una compleja estructura económica a lo largo del mundo cristiano, creando unas técnicas financieras predecesoras de la banca. Tener el poder económico les permitió poder construir fortalezas por todo el Mediterráneo y Tierra Santa.

La Orden del Temple participó de forma muy activa en las cruzadas y en la toma de Jerusalén. Las derrotas ante Saladino en 1187 en la llamada batalla de los Cuernos de Hattin les llevó a perder influencia. Los cruzados a las órdenes de Guido de Lusignan, rey de Jerusalén, y Reinaldo de Chatillon se enfrentaron a las tropas del sultán de Egipto $y$ fueron derrotadas, cayendo prisionero el gran maestre de los templarios, Gérard de Ridefort. Saladino tomó por tanto posesión de Jerusalén y terminó con el reino que había fundado Godofredo de Buillon. Fue más tarde y debido a la tercera cruzada, dadas las victorias y acuerdos llevados a cabo por Ricardo I de Inglaterra, que se convirtió Jerusalén en ciudad libre para el peregrinaje.

La orden comienza su implantación en la zona oriental de la península Ibérica en la década de 1130. El conde de Barcelona, Ramón Berenguer III, pide la entrada en la orden y en 1134 en el testamento de Alfonso I de Aragón les cede su reino a los templarios, junto a otras órdenes como los hospitalarios o la del Santo Sepulcro. Los nobles aragoneses no estuvieron de acuerdo con el mencionado testamento y entregaron la corona a Ramiro II. Se buscó en realidad la alianza con Barcelona, lo que llevaría al nacimiento de la Corona de Aragón.

Los templarios se convirtieron en custodios del heredero de la Corona de Aragón en el castillo de Monzón tras la derrota de Muret, que su- puso la pérdida de la zona transpirenaica aragonesa. Jaime I el Conquistador recibió la ayuda de los templarios en sus campañas de Mallorca. Los templarios se asentarían en Aragón gracias a la absorción de la Orden del Santo Redentor de Teruel en 1196.

En el año 1319, con la disolución de la Orden del Temple, el castillo pasó a manos de la Orden de Montesa, que amplió la fortaleza. El estilo arquitectónico corresponde a una arquitectura gótica de marcado carácter románico puro y estilo cisterciense, austero y castral. Los muros construidos con piedra labrada y sus dependencias se cubren con bóvedas de cañón. Destaca en todo el conjunto la sobriedad y solidez de su construcción, con un cierto parecido a la construcción del castillo de $\mathrm{Mi}$ ravet, construido unos ciento cincuenta años antes. Uno de los mayores intereses arquitectónicos del castillo se centra en la solución abovedada del cuerpo de guardia y en la austeridad de la basílica de los Templarios. Son de interés también las dependencias pontificias mandadas construir por el papa Benedicto XIII.

La fachada principal de acceso al castillo fue construida entre los años 1294 y 1307, ofreciendo una única puerta de acceso al interior de la construcción. La puerta, formada por un arco de medio punto, está flanqueada por dos torres cuadradas y salientes que protegen el acceso; una de ellas fue derruida en el siglo xIx durante la guerra de la Independencia. Sobre la puerta hay una serie de sillares esculpidos con emblemas heráldicos, en los que se aprecia la cruz negra de la Orden del Temple, los cardos, emblema del maestre de la orden, fray Berenguer de Cardona, y las fajas de Arnaldo de Banyuls, comendador de Peñíscola. La obra fue terminada por la Orden de Montesa, de ahí que figure el escudo heráldico de fray Arnaldo de Banyuls comendador de dicha orden. Por encima de esta serie de escudos heráldicos, observamos una ventana gótica de tres puntas. La entrada principal da paso a un zaguán desde el cual se accede al cuerpo de guardia situado a la derecha y, enfrente de un gran salón rectangular que corresponde a los antiguos establos, en el zaguán, se encuentran también la escalera de acceso al patio de armas y demás dependencias del castillo. 
El cuerpo de guardia está formado por dos dependencias: el antiguo cuerpo de guardia de la fortaleza y la planta inferior de una de las torres defensivas de la puerta. Estas conservan las trazas de la antigua escalera medieval de la fortaleza, estando al fondo un acceso abierto a la pieza utilizada durante siglos para aljibe colector de aguas pluviales de la plaza de armas.

Los establos están situados en una amplia sala rectangular de bóveda ligeramente apuntada. Al fondo encontramos dos habitaciones, la más extrema corresponde a la planta cuadrangular de la torre destruida en el siglo xix y que se había utilizada como polvorín. En el umbral de acceso a la habitación se encontró un fragmento de la piedra armera de la familia aragonesa de los Alagón, señores de Peñíscola, en los últimos veinticinco años del siglo XIII.

Desde el zaguán de entrada y subiendo una empinada escalinata, llegamos a través de un arco apuntado a la plaza de armas, cerrada por tres de sus lados por dependencias del castillo y, en la parte frontal, por una gran balconada sobre el mar y el acantilado. A un lado y a otro se sitúan la iglesia, el salón gótico y, a la derecha, en la torre, las dependencias de Benedicto XIII.

El salón gótico es la sala más majestuosa del castillo y Benedicto XIII la adaptó como sede pontificia. Su interior, de planta rectangular, tiene bóveda de medio cañón y muros de sillería labrada con ventanales góticos. Es la dependencia que resalta más en toda la construcción; a ella se accede a través de una puerta con arco de medio punto que tiene su acceso desde el patio de armas a través de una pequeña escalera. Sobre la puerta de entrada se encuentran los escudos heráldicos de fray Berenguer de Cardona, maestre de la Orden del Temple a finales del siglo XIII. En tiempos de Benedicto XIII este salón estaría suntuosamente decorado como corresponde a una sede pontificia. Desde dicho salón hay una puerta que comunica con las dependencias del palacio residencia.

Existe también la llamada dependencia de la cisterna: es una sala bastante amplia de forma rectangular que alberga un brocal de un pozo en el cual se acumulaba el agua del aljibe. Esta sala se comunica por dos puertas con el salón gótico y con un patio exterior, resto de la antigua torre de la que solo se conserva una planta.

La iglesia es una amplia sala rectangular con bóveda de medio cañón apuntada cerrándose en un ábside semicircular. En un principio, fue dedicada a la Virgen María y a los Reyes Magos y, antes de servir como basílica pontifical a Benedicto XIII, fue capilla de los monjes templarios. Varios ventanales iluminan su interior en el que se conservaba el altar de piedra en el que celebraban misa Benedicto XIII y sus cardenales. A la derecha y al pie del ábside estuvo depositado de forma temporal el cuerpo de Benedicto XIII hasta su traslado al poco de su fallecimiento al castillo de Illueca, en la provincia de Zaragoza, casa solariega de los Luna. A la iglesia se accede por el patio de armas, a través de una puerta de medio punto adornado en su parte superior con el blasón del maestre del temple fray Berenguer de Cardona.

Frente a la puerta que da acceso a la plaza de armas, en 1923 se colocó una lápida en mármol negro en la que figura el escudo papal, la enseña aragonesa y la siguiente leyenda:

Aragón os pide que roguéis a Dios por Benedicto XIII, Pedro de Luna, el gran aragonés de vida limpia, austera, generosa, sacrificada por una idea de deber. El juicio final descubrirá misterios de la Historia. En él nos salve Jesucristo y Santa Maria su madre.

Fue colocado por universitarios de Zaragoza en recuerdo al quinto centenario de la muerte de don Pedro de Luna. La basílica, que fue utilizada por

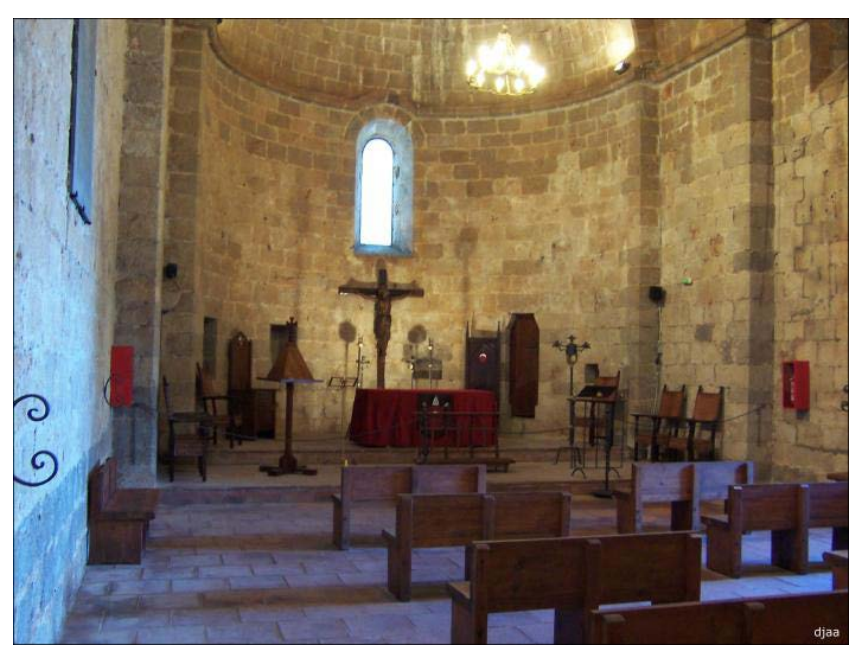

Figura 2. Altar mayor y ábside de la iglesia del castillo 
Benedicto XIII y por su sucesor Clemente VIII, tiene las características constructivas del resto de estancias. El presbiterio está formado por un ábside semicircular, cubierto por una media cúpula de cascarón encumbrada sobre un arco toral, y un pequeño ventanal situado en el centro del ábside.

Junto a la iglesia, en un nivel inferior al que se desciende desde la plaza de armas, se encuentra el llamado salón del conclave. Es una sala rectangular que, al igual que las demás dependencias del castillo, se cierra con una bóveda de medio cañón en sillería. Este salón se ilumina con una pequeña claraboya y unas mínimas aspilleras. Los peldaños de la escalera conservan su primitiva planta medieval. En este mismo salón celebraron el cónclave los cardenales asignados a la muerte de Benedicto XIII para elegir su sucesor.

Cuando llegó Benedicto XIII a Peñíscola, puso el castillo bajo la protección de la Santa Sede, sustrayendo la villa y el castillo de la jurisdicción de la orden de Montesa. Permaneció refugiado en el castillo entre los años 1415 y 1423 y se realizaron reformas de las estancias en dicha época, con el fin de readaptarlas como residencia del papa y su corte en el exilio.

Al palacio se accede desde el patio de armas y se encuentra situado sobre el cuerpo de guardia, en realidad, es una torre, la del homenaje, dividida en tres plantas con diversas estancias en las que se unen los estilos románico primitivo y gótico. En la parte inferior, se encuentran tres estancias papales; en una de ellas es probable que se encontrara la biblioteca que en 1423, año de la muerte de Benedicto XIII, contaba con más de mil volúmenes manuscritos que pasaron después a la biblioteca vaticana, a la de Foix y a la de París. En la parte superior, hay una sala estudio que se dice era la preferida del Papa; es una sala no muy amplia, con muros de sillería. En la puerta de esta estancia está grabado el escudo de Pedro de Luna con la tiara y las llaves de san Pedro y la media luna menguante de la casa de los Luna.

El castillo dispone de cinco torres cuadrangulares. Sobre la parte externa del salón del conclave se desciende hasta la misma mar por una escalera que se llegó a utilizar como embarcadero de urgencia labrada en la misma roca del peñón: es la famosa escalera del Papa Luna. Junto al salón gótico, por una escalera, se accede a las grandes terrazas superiores que cubren toda la extensión de la iglesia y del salón gótico.

\section{Murallas}

Las murallas que conforman el perímetro de la antigua ciudadela y el castillo forman parte del conjunto arquitectónico y patrimonio que expongo. En dichas murallas se distinguen tres zonas que corresponden a estructuras arquitectónicas y militares diferentes, disponiendo de tres puertas de acceso: San Pedro o del Papa Luna, portal Fosc o de Felipe II y la puerta de Santa María construida en el siglo XIII. Las murallas existentes en las caras sur y este del castillo pertenecen a los siglos XIII y XV. Las murallas de la cara sur se elevaban unos nueve metros sobre el nivel del mar, formando un muro sobre la línea rocosa al borde mismo del acantilado, siguiendo un trazado poligonal, adaptándose al terreno y con torreones cúbicos.

El portal del Papa Luna del siglo xv (figura 3) es un gran arco rebajado, construido con piedra de sillería que, en su dovela central, luce el blasón en piedra de Pedro de Luna. Era el acceso a la fortaleza desde el mar, cuando el agua llegaba a la rampa de acceso y las barcas varaban en la misma rampa al pie de este portal. Lo mandó construir el Papa Luna en el año 1414 y hasta el siglo XIII ejerció su función. En esta época y por motivos militares, fue cegada esta entrada procedente del mar y se convirtió en una entrada más de tierra firme. Su arquitecto fue Filibert Bertalla. De esta época es también el llamado fortín del Bonete y el primer tramo de muralla de la fuente junto al portal mencionado y que corresponde a los siglos XIV y XV.

En el siglo XVI y como reordenación defensiva de la costa por mandato del rey Felipe II, fueron construidas las murallas renacentistas, proyectadas por el ingeniero militar italiano Juan Bautista Antonelli. Dicho ingeniero militar construyó diversos baluartes y fuertes militares en Europa para la corona española durante la segunda mitad del siglo XVI. En 1568, Felipe II encargó a Antonelli y a Vespasiano Gonzaga la inspección y preparación de varios proyectos de construcción, entre los que destacan la fortificación del puerto de la ciudad de Carta- 


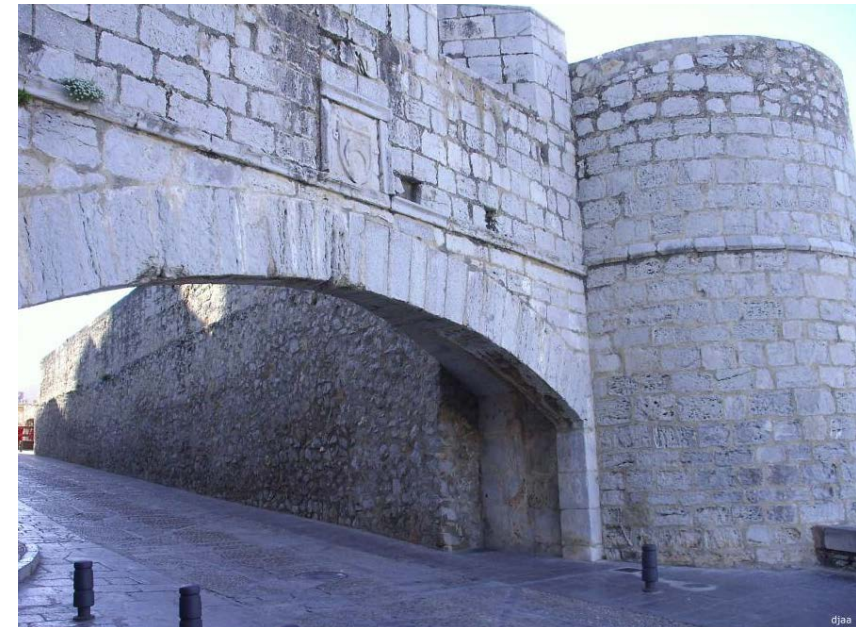

Figura 3. Portal del Papa Luna

gena, la costa del reino de Valencia y los puertos africanos de Orán y Mazalquivir. Se acometió así mismo la reconstrucción del castillo de Santa Bárbara en Alicante en 1562, la construcción del castillo de Benidorm y la torre vigía de Santa Faz en Alicante en 1575. De esta época son las murallas de Peñíscola renacentistas, los baluartes estrellados y la adaptación para el fuego de artillería de costa.

La estrechez de los caminos de ronda medievales y la reducida plataforma de las torres exigieron una evolución hacia el tipo de fortificación abaluartada en la que las torres se achatan y ensanchan para convertirse en baluartes en donde las piezas de artillería pueden ser maniobradas. Juan Bautista Antonelli aplicó los conocimientos de arquitectura militar de su época para realizar el diseño de estas torres. Estos procedimientos podemos citar que se

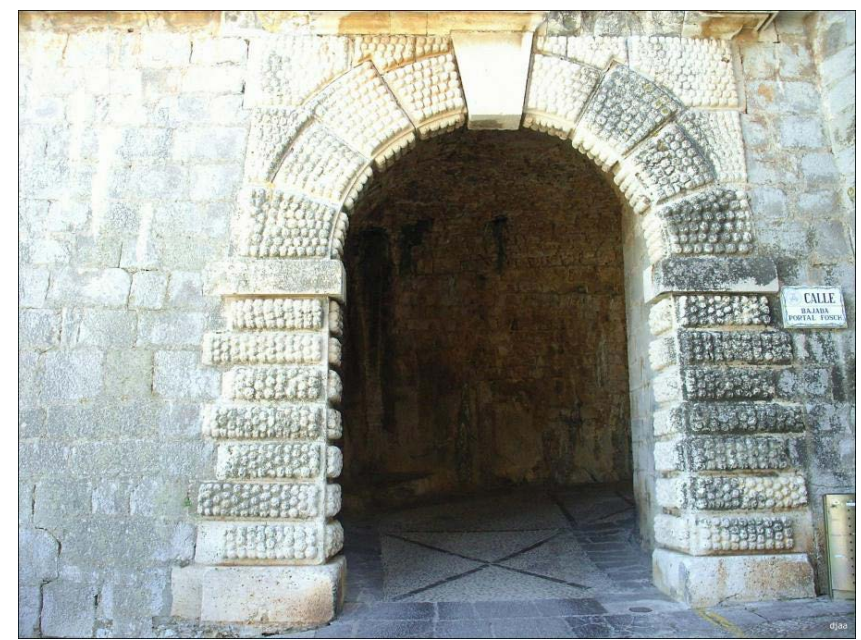

Figura 4. Portal fosc repiten en otras construcciones coetáneas como las de Mallorca, Tabarca, Palma, El Frantin o Calvi, todas ellas proyectadas por ingenieros militares italianos a las órdenes de Felipe II.

La característica principal de estos baluartes es la composición en planta estrellada. Construidos con bóvedas internas huecas o acasamatadas de gran resistencia, donde se podían albergar arsenales cantinas y polvorines, las zonas superiores aterrazadas o baterías, los muros exteriores de sillería ataludados con el cordón corrido que resuelve los cambios de plano y las garitas de vigilancia para ofrecer amparo volado en las esquinas. Un ejemplo de ello es el llamado balcón de Pilatos. Las baterías reciben los nombres de Santa María, Olvido, Santiago, San Fernando, Fosos y el balcón de Pilatos o de Felipe II.

De la época de intervención arquitectónica renacentista proviene el portal Fosc (figura 4) construido en 1578. Es una obra en piedra ornamentada con un tosco almohadillado en piedra blanca y motivos militares que contiene una bóveda interna resuelta en ángulo de $90^{\circ}$ desde la que se accede al cuerpo de guardia. Sobre la puerta hay un escudo conmemorativo de Felipe II. Esta puerta fue la entrada principal de la ciudad hasta el siglo xvin y fue atribuida por algunos historiadores a Juan de Herrera. Destacan en las murallas las garitas de vigilancia y el escudo del rey Felipe II con el blasón de Portugal.

Ya en el siglo xviII, el recinto amurallado tenía la configuración actual. Las últimas obras relevantes se realizaron en la segunda mitad del siglo XVIII, con la ampliación de las instalaciones para albergar una guarnición más numerosa, la edificación del almacén de pólvora, el baluarte del Príncipe y el portal de Santa María en 1754, mandado construir por Fernando VI quien atendió los deseos de la población para abrir un acceso perforando la fortificación, facilitando con ello el acceso para la introducción de cosechas y mercancías en carro que, hasta el momento, eran realizadas a través del portal Fosc, de acceso difícil por su rampa.

Durante una inspección rutinaria en el año 1993 de los muros del castillo por parte del arquitecto don Arturo Zaragoza, se encontró en la cara exterior de una de las murallas de Santa Bárbara, la represen- 
tación de setenta y cinco figuras de embarcaciones, grabadas con un instrumento punzante. Se efectuaron estudios posteriores por parte del Servicio de Investigaciones Arqueológicas y Prehistóricas de la Diputación de Castellón, realizadas por Francesc Gusi y Arturo Oliver, aconsejando que este conjunto de representaciones marineras debería formar parte del conjunto expositivo público del Museo del Mar, recomendando su cuidado para evitar el deterioro.

Varios historiadores apuntan que, por el tipo de embarcaciones representadas, los grabados fueron realizados a finales del siglo XVII o mediados del siglo XVIII. Entre los barcos representados se observan navíos como el barquete, la tartana catalana, la galera, la galeota o los buques artillados de dos y tres puentes.

Lo más interesante, según Gusi y Oliver, es la presencia de dos buques de línea de primera clase, con tres puentes y fuertemente armados con más de cien cañones. Estos técnicos apuntan a que la representación obedece a dos posibles tesis: el hecho de representar por personas residentes en la población lo que estaban observando desde la playa o recordar algún acontecimiento naval producido fuera de las costas de Peñíscola.

El investigador local Vicent Meliá ha considerado que, más que una representación artística, estos grafitos buscan un objetivo pedagógico: son apuntes y esquemas para soporte didáctico en un proceso de formación. Meliá defiende que en Peñíscola existió una escuela de navegación, fundada al principio del siglo XV por Benedicto XIII en torno a la biblioteca pontificia y que llegó hasta finales del siglo XVII.

\section{Iglesia de Santa María}

El templo parroquial de Santa María denominación esta que data del año 2005 (con anterioridad se llamó Virgen del Socorro, advocación mariana del templo desde el siglo XVIII), se comenzó a construir en el año 1234 y responde al origen de la típica iglesia de la reconquista, construida sobre los restos de una antigua mezquita árabe. A mediados del siglo $\mathrm{xv}$, un voraz incendio destruyó la iglesia y, entre los años 1725 y 1739, el templo se reconstruye y se amplía bajo la dirección del maestro José Antonio Simó. Con anterioridad, gracias a la indulgencia plena a los donantes, concedida por el papa Eugenio IV, y a petición de la reina María de Castill, se había comenzado su reconstrucción cubriéndose las capillas laterales con ladrillos y yeso a final del siglo xvir. El campanario fue construido en el año 1862 según diseño del arquitecto Vicente Martí.

El templo consta de dos partes diferenciadas: la primitiva iglesia del siglo $\mathrm{xV}$, con algunos antecedentes del siglo xIII, como la portada de entrada, $y$ la construcción y ampliación llevada a cabo durante el siglo XviII con la construcción del crucero y del presbiterio. La iglesia es de planta de cruz latina con una nave dividida en cuatro tramos cubiertos de bóveda de crucería con nervios y claves de sillares complementaria de mampostería y las impostas de los arcos torales esculturadas. El crucero y el presbiterio tienen mayor altura y están cubiertos por una bóveda de cañón con lunetos. El presbiterio está rodeado por la sacristía, el trasaltar y la capilla de la comunión.

En la fachada, cabe destacar la puerta de entrada al templo, construida en arco de medio punto, rodeado el arco por una moldura circular. La torre del campanario, adosada al lado del evangelio de la iglesia por donde se accede, es de planta cuadrada. Se observa que tiene tres cuerpos separados por molduras y una azotea con barandilla coronada por pináculos.

Es de interés conocer el tesoro parroquial desde el punto de vista histórico. Ocupan el interés las piezas góticas que lo componen, pues son testimonios mudos del gran cisma de la cristiandad, son recuerdos personales de Benedicto XIII. La cruz procesional gótica tiene el árbol y los brazos de fino cristal de roca festoneado de afiligranada crestería gótica de plata dorada. La macolla muestra imágenes religiosas de esmaltes. Ostenta el blasón del pontífice (luna menguante, tiara y llaves) y, como curiosidad, el escudo de Valencia, el conjunto es obra de un orfebre de Sant Mateu. El cáliz del Papa Luna pertenece a orfebrería gótica catalana con el emblema pontificio burilado en la base de la joya histórica. El lignum crucis, relicario de su sucesor dimisionario don Gil Sanchez Muñoz, es 


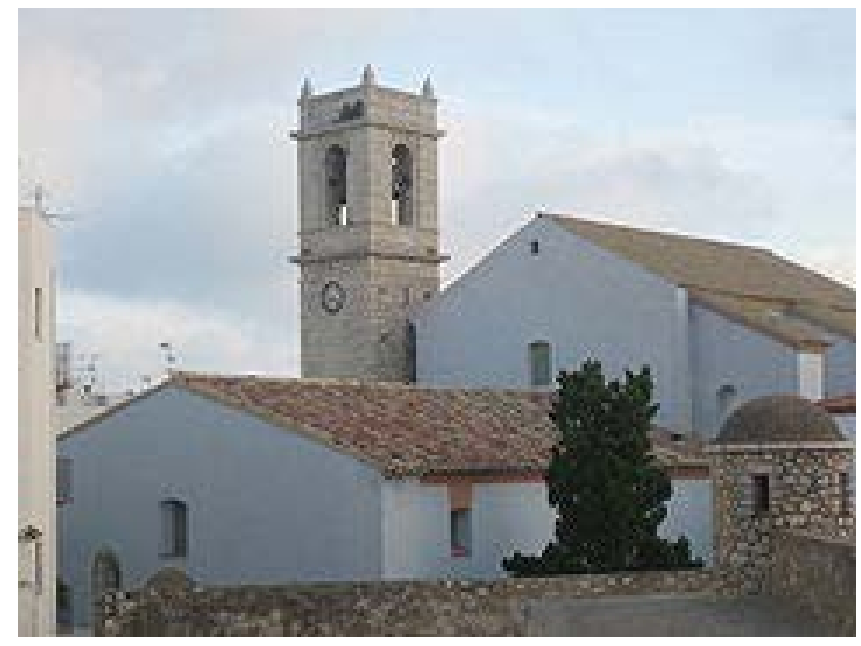

Figura 5. Iglesia parroquial de Santa María

una preciosa obra de arte gótico valenciano, con abundantes esmaltes y blasón del noble turolense. Se completa con la cruz procesional de Felipe II, fabricada en plata.

\section{Casa de las conchas}

La casa de las conchas (de les petxines) podemos considerarla patrimonio de la población dada su arquitectura y decoración popular que la hacen destacar del resto de construcciones de la villa. Pocas personas, de todos modos, conocen su historia. Sus muros repletos de conchas marinas representan la búsqueda de la libertad.

Fue construida por el matrimonio formado por Timoteo Pau Beltrán, nacido en Peñíscola, y por Justa Mir Soria, aragonesa nacida en Maella, provincia de Zaragoza. Por su militancia libertaria durante la guerra civil (1936-1939), Justa Mir fue encarcelada en la prisión de mujeres de Amorebieta, en Vizcaya, y condenada a cinco penas de muerte. Tras largos años de presidio y por la influencia de las relaciones sociales que tenía su padre, cantante y pianista del Gran Teatro del Liceo de Barcelona, este consiguió la intermediación en la causa de Justa de una familia noble catalana muy relacionada con el Movimiento Nacional y, tras largas gestiones burocráticas, fue indultada, regresó a Peñíscola junto a su marido y comenzaron la construcción de esta curiosa casa.

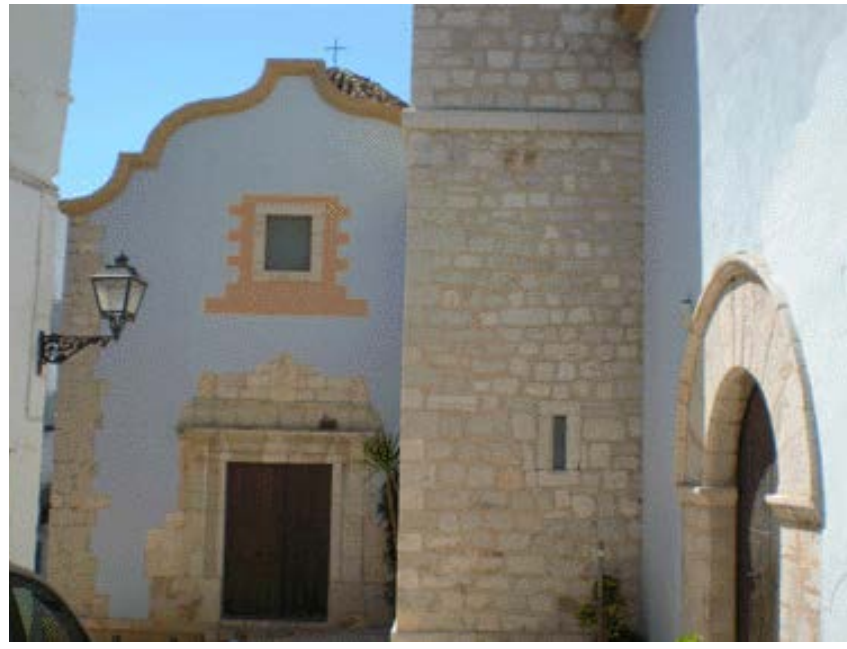

Figura 6. Puerta de entrada a Santa María

\section{Ermita de la Virgen de Ermitana}

Peñíscola se declaró partidaria del bando borbónico de Felipe de Anjou en la guerra de Sucesión al trono de España, junto a su gobernador militar Sancho de Echevarría. El reino de Valencia y la mayor parte del reino de Aragón se declararon partidarios del bando austriaco. Peñíscola fue sitiada durante dos años por ingleses y holandeses, en la llamada batalla de trincheras. Tras resultar vencedor de la guerra el duque de Anjou, entronizado con el nombre de Felipe V, declaró a Peñíscola como ciudad, con los títulos de muy noble, leal y fidelísima ciudad. Es como agradecimiento y conmemoración de esta victoria militar por lo que Sancho de Echevarría manda construir la ermita, entre los años 1708 y 1714 , en honor del triunfo en la guerra y en honor a la patrona de Peñíscola, la Virgen de la Ermitana, construida junto al castillo templario. Sancho de Echevarría no pudo ver la conclusión de su obra dado que murió el mismo día de su inauguración; su cuerpo se encuentra enterrado a los pies del altar mayor de la iglesia.

La planta de la iglesia tiene una estructura en cruz latina, con una nave y dos capillas laterales, cubierta con bóveda de cañón. La cabecera es plana con un templete construido en piedra de Tortosa. La fachada está rematada con una cornisa mixtilínea con pináculos enmarcando el escudo de Felipe V. En el centro consta de una portada con dintel, con sillares almohadillados similares a los existentes en el portal Fosc de la muralla renacentista y decorados con motivos militares. La torre del campana- 


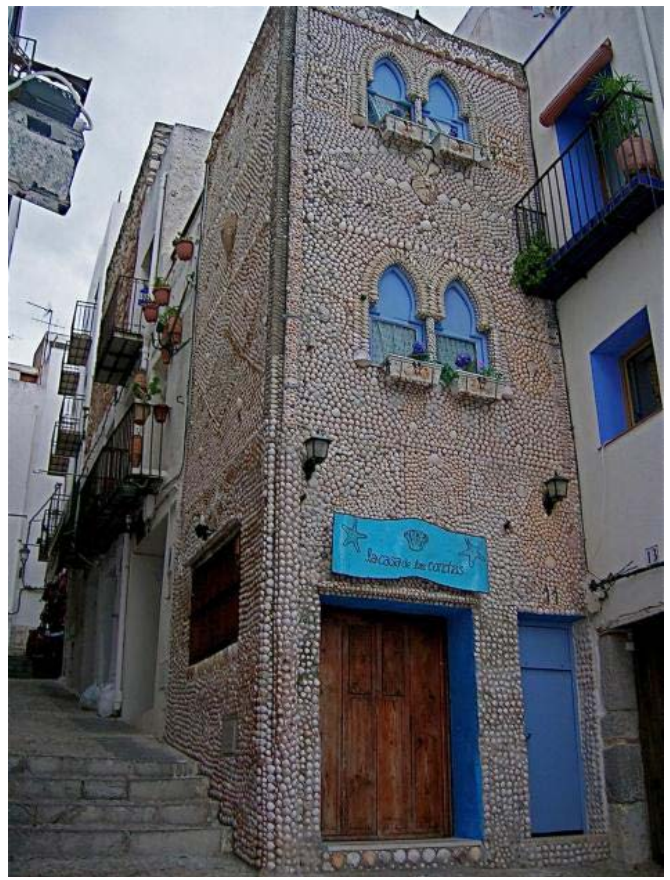

Figura 7. Casa de las conchas

rio es de planta cuadrada y consta de dos cuerpos. Creencias recogidas por historiadores y literatos como Vicente Blasco Ibáñez afirman que el apóstol Santiago entró en España por Peñíscola y que en el desembarco murieron dos de sus seguidores, los cuales fueron enterrados en lo que hoy es la plaza de la Ermitana. Otra leyenda afirma que el campanario de la ermita se edificó dentro del espacio de la propia iglesia, porque en el lugar sobre el que debía ser construido se encontraban las tumbas de los dos seguidores del apóstol Santiago mencionados.

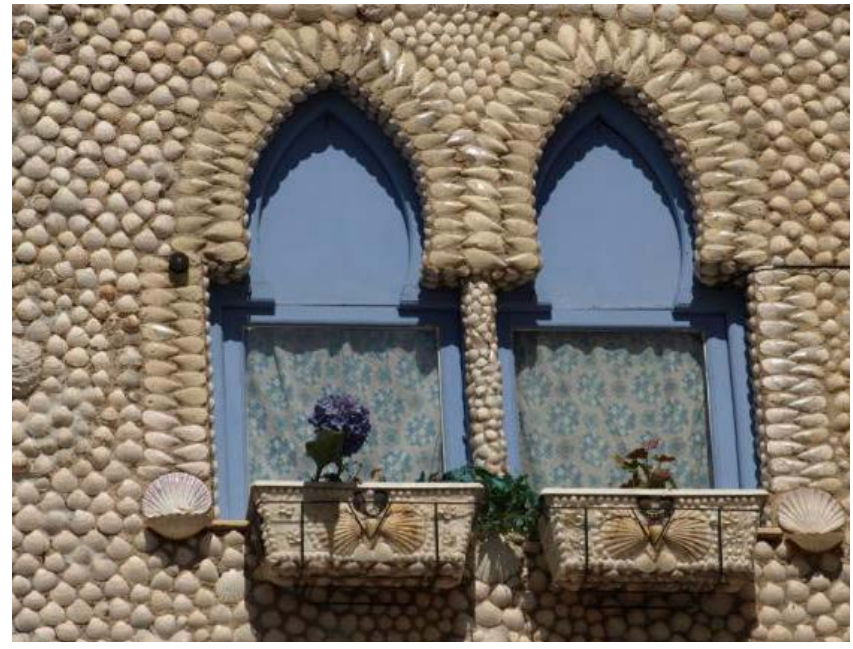

Figura 8. Detalle ventana de la casa de las conchas

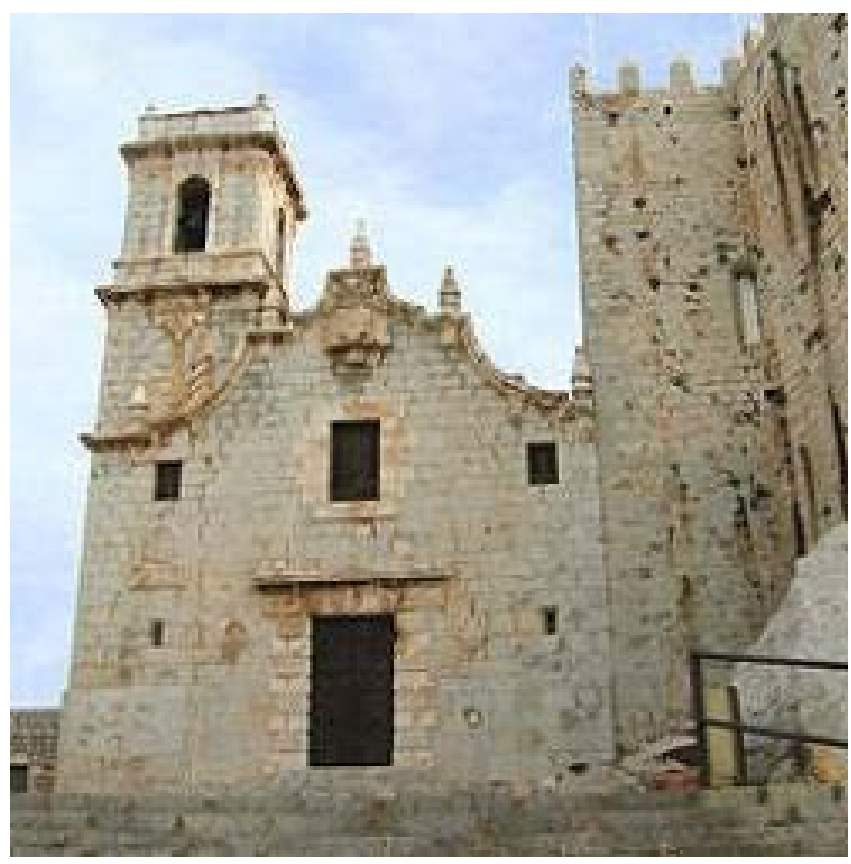

Figura 9. Ermita de la Virgen de la Ermitana

\section{Referencias}

Álvarez, V. A. (1982). El Cisma de Occidente. Rialp. Madrid.

Archivo de la Corona de Aragón. Bulario de Benedicto XIII.

Augé, M., Colleyn, J. P. (2005). Qué es la Antropología. Editorial Paidós. Barcelona.

Avila, R. P. (1949). Historia de la Iglesia. Editorial San Benito. Buenos Aires.

Honorio, M. V., Cruces, F. y Díaz, A. (2010). Lecturas de Antropología Social y Cultural. Uned. Madrid.

Levi-Strauss, Claude (1995). Antropología estructural. Ediciones Paidós. Barcelona.

Ockham, W. (200). Stanford Encyclopedia of Philosophy. Standford University.

Sánchez-Albornoz, Claudio (2000). España un enigma histórico. Edhasa. Barcelona. 